\title{
Hold the candle: mission at the crossroads in our era
}

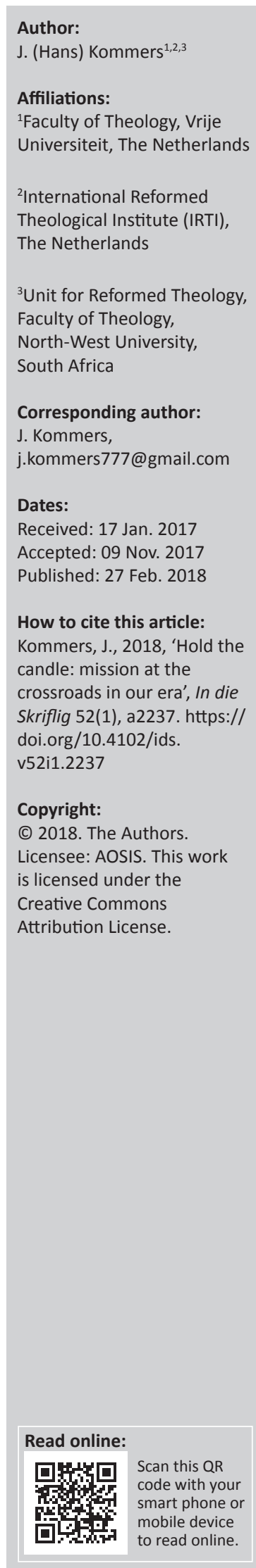

When we rounded the bend from the second to the third millennium the contribution of the classic pioneer missionary is over. The 21st century is dominated by a holistic approach. However, in using new methods, new technology and in adapting a lifestyle according to this time, there is a tendency to view the work of pioneer missionaries as old fashioned. With a new approach and new methods also new ideas enter the field. My intention is not to defend the pioneers and to give them more recognition - the Lord will honour his own work and workers but to show that we do ourselves an injustice when we would not use the knowledge, experience, love and passion of the former generations who just had only one vision. We need them to fuel our mission intention in obeying Christ's last commend in the conviction that the message of the cross of Jesus Christ is the only relevant message for today's world.

After this I looked and there before me was a great multitude that no one could count, from every nation, tribe, people and language, standing before the throne and in front of the Lamb.

- Revelation 7, 9 (NIV)

\section{Introduction}

A decade after the Second World War the Dutch missiologist Hendrik Kraemer (1960:17) was almost certain that we had reached the end of a particular era in mission, but not the end of mission. The turbulent 1960s, initiated by students all over Europe, tore apart economic, social and spiritual values which were for generations fixed in a certain recognised system. Western society went through a crisis and the 'baby boom' generation had to face the insecure reality, because the self-assurance of the past had gone. The different mood of Western society became clear in the fact that the individual came more in the centre and this affected the ecclesiastical climate. Long existing missionary societies, as the primary instruments of mission, had remained nearly unchanged until half the 20th century. In addition, these societies fell under the critic of modern thought, because their historical character made radical change impossible. The claims of mission societies were held under a magnifying glass. Does mission work become objectionable when it maintains the claim that only she knows the truth? Today's mission agencies working on an effective mission strategy for the 21st century are confronted with the urgency to change and to require new skills while staying true to eternal values. One can feel that former mission strategy for today is an 'unbridgeable' far distance due to a complete different world. In other propositions with other problems, even in the issues of the apostolic task of the church, do we recognise unchangeable values which must not get lost and which belong intrinsically with the now on us loaded task by Christ to evangelise the world?

\section{The postmodern world}

Concerning the above-mentioned question, is it a subject in today's missiology? Is it a hot issue or is it marginalised due of other trending topics? What does the 21st century look like? A Boston University history professor (Landes 2001) calculates that:

we live at a moment when social, economic, and technical change occur at speeds and with a scope never before seen in the history of mankind, at a time when cultures, religions and lifestyles are rubbing shoulders as never before, such 'big thinking' would seem appropriate. And yet, we have done everything but think big. [...] Never in history have cultures been in such complex contact around the globe, never has the culture of the aristocratic cosmopolitans had so deep an impact on the lives of commoners everywhere, and with growing importance, vice-versa. This is all unknown terrain. How do we think about it, and talk about it? (p. 1)

Seen from a Christian perspective, we see a world characterised by losing the ethical values which were the consensus in the society. At least this is applicable for the Western world. Methodical doubt replaced the biblical message within a 200 years process and led to confusion of the traditional religious conviction (cf. Hardmeier 2012:20-28). The deciding impulse to form this 
world for the first time did not come from churches, but out of the influence sphere of the church from science, philosophy and psychology. Human ingenuity becomes the new authority which only appeals to oneself and not on an instance outside the church. One can speak of a 'crisis of her legitimating' (Hardmeier 2012:23). This crisis is strong in our postmodern society. Pluralism forms the big framework in the society in which the church lives with her mission. A retreat into a Christian ghetto cannot be a solution; it is even impossible. Christianity has lost its authoritative power across the society and it is undeniable that in this process of de-Christianisation everything is changing in the world around us. Religious diversity will have its contribution on the pressing mission questions we face. Taken this seriously, we see that these events hit traditional missions which, as some fear, are carried away in this process.

Change is inevitable, but in what way in order to remain effective and not to lose the main motives of the mission starting-point? Jenkins $(2002: 2,3,14)$ makes the stunning prediction that Christianity should enjoy a worldwide boom in the 21st century, and the emerging Christian world anchored in the Southern continents. 'The era of Western Christianity has passed within our lifetimes, and the day of Southern Christianity is dawning'. Christianity is almost present in every country in the world - even in North Korea and a viable indigenous church is found in most countries. Living in a globalised world makes it possible to physically reach the other end of the world within 24 hours and, by means of the Internet, gospel servants have access within seconds to the most remote places all over the world. Christianity can widen its borders, but what about the depth? In Africa, for instance, prosperity churches flourish, but only those who are successful in business, profit from it. Modern technology will accelerate this development all over the world (cf. Bangura 2013:169-196). The downside of globalisation brings its own philosophy of life. In a globalised world, 'it should not surprise us that we are influenced by these currents around us' (Hiebert 1999:1). As a result, we see that our society, also the Western society, which has been the main sender of missionaries, is more and more burdened with materialism and pluralism. Materialism tends to smother spirituality and eventually drives out godliness. Pluralism strikes deep at the foundations of values and erodes the biblical faith. With the entering of modernity in Christian faith, science became a dominant form from which many Christians created their knowledge. The epistemological foundation was 'positivism' (Hiebert in Van Engen 2008:13). Theological positivism holds that our central concern is truth and that our theology corresponds one-to-one to Scripture. This view deeply shaped the modern mission movement and persuades the people that all human knowledge is shaped by cultural and historical contexts.

Looking at the future of the worldwide mission work, can we frame the current realities and map out the future possibilities? There is a continuous call for contextualisation in which conversion calls for a minimum of cultural dislocation. Of particular value is the perspective of those who, themselves, were objects of missionary activity and who reflect upon this experience. Especially from the side of anthropologists who see missionaries as destroyers of cultures and Christianity as arrogant in its exclusive claims to be the only way to God. In this concept, mission work becomes a ministry to people according to their felt needs. It is important that missionaries examine their own cultural assumptions in the light of biblical teachings. The gospel is not an abstract truth; it is a living relationship with Jesus Christ and it involves the receiver in a cognitive, affective and moral way. The relevance is undeniable as it claims finality for Christ. According to Newbigin (Weston 2006:65), it is the 'true clue to history' and in the future mission workers 'see the pattern of Cross and Resurrection thrown on to the screen of world history'.

\section{An overnight guest shuffling around}

A headline in today's missionary debate is 'holism'. Globalisation asks for a holistic approach and 'refers both to the compression of the world and the intensification of consciousness of the world as a whole' (Robertson 1982:8). Its connotation is the 'increasing interconnectedness of the world as a single place and the consequences and dynamics of the growing interconnectedness' (Bliese 1997:172):

Globalization refers to the increasing global interconnectedness, so that events and developments in one part of the world are affected by, have to take account of, and also influence in turn, other parts of the world. It also refers to an increasing sense of a single global whole (WEAG 2003:2).

For two millennia, the Christian gospel has been heard in the world. Within one generation, a small number of followers of Jesus Christ penetrated into the main cities of the Roman Empire. Not a world-conquering majority they found themselves in an 'emergency situation' (Bosch 2001:489). The church consolidated her on the European continent and, except for the work of some individuals, the 'regions beyond' receded from the focus of the church. The church was more interested in its own theology and theological wars and more and more lost the vitality of the beginning, and due to the hierarchy and the abstract academic theology, gospel service 'on-the-road' diminished. The Reformation in the 16th century stirred the churches in Europe. The Roman Catholic Church started mission work where Spanish and Portuguese fleets opened new ports in yet unknown areas. The principle 'gold and God' drove explorers and Christian witnesses into the Asian, African and the newly discovered American continent. Protestant theology, as a disciplined scientia, became a technical and specialised scholarly undertaking in Europe, and in that, undertaking missionary work was a marginalised entity. The vitality of the Reformation was stifled in academic debate.

In the Protestant world the eyes for mission work were opened in the second part of the 18th century and since then, from the European continent, the British Islands and America, thousands crossed the oceans and gave their life - often literally - for the salvation of those yet unknown with the Name of Jesus Chris. It must be said that where the disposal of life is considered there are not too many available with a 
surrender as complete as these men and women offered to their Lord. ${ }^{1}$ In academic circles, missions became a recognised discipline and students were introduced in missiology. For many missionaries their first interest in missions was kindled in the university. A famous example is the 'Cambridge seven' - high class students from Cambridge and Oxford left all the earthly wealth and prospects to serve on the mission field relying on God's promise for provision. ${ }^{2}$

Missiology gained the status of a full-blown discipline in the theological curriculum in the late 19th century with the direct result of an explosion in the number of chairs in this field all over the world. Still by the 1950s mission work, missiology and missionaries were, as Conn remarks (Ortiz \& Baker 2002:16) 'too often like some forgotten, marginalised, and peripheral "department of foreign affairs" for the seminaries'. In 1950 the Association of Professors of Missions came into existence in the USA, but in 1956 missiology was excluded as a subject field by the Association of Theological Schools directed by H.R. Niebuhr (cf. Thomas 1990:14). In the Netherlands in the 1980s Utrecht University had a professor for Missiology and a Mission institute. Nowadays, in many university faculties, the exclusive claims of Christianity were faded away and missiology is to be found in the curriculum of intercultural studies or is part of Practical Theology. The loss of mission studies is to be seen in the declining number of academics preparing themselves for the mission field. J.H. Bavinck became professor of missiology at the Free University of Amsterdam in 1939. Through his influence, many students were triggered to go to the mission field themselves. Conn (in Ortiz \& Baker 2002) gets the point when he writes:

And mission particularly [...] was a colourful extra, still looking for its place in the theological sun. Missiology 'sounds like an overnight guest shuffling around in bedroom slippers in the palace of the theological seminary'. (p. 16)

Theology has to join the missionary community in their hermeneutical research to discern God's word for today's generation. J.I. Packer (1977) writes about the divorce of theology and missiology:

Evangelism and theology, for the most part, go separate ways, and the result is a great loss for both. When theology is not held on course by the demands of evangelistic communication, it grows abstract and speculative, wayward in method, theoretical in interest and irresponsible in stance. When evangelism is not fertilized, fed and controlled by theology, it becomes a stylized performance seeking its effect through manipulative skills rather than the power of vision and the force of truth. Both theology and evangelism are then, in one important sense, unreal, false to their own God-given nature; for all true theology has an evangelistic thrust and all true evangelism is theology in action. (p. 91)

Missionaries, by the very nature of their task, are theologians, and in the words of Martin Kähler (1971:190), mission is 'the mother of all theology'. All theology originated from mission!

1.See the records of consecration in the annals of the China Inland Mission (now OMF) and the American Board of Missions.

2.Compare the huge influence on mission work of C.T. Studd (1860-1931), a most famous cricketer of that time and others from nobility.
Nowadays the question is for a more just, humane and ultimately redemptive globalisation. But in mission the church in the world demands that those who profess Jesus Christ as Lord and Saviour of all creation, be his standard bearers and his kingdom announcers to a fallen humanity in a broken world. Called, from university level to the grass roots, clergy and laity, individually and collectively, globally and locallyall bear witness to God's sovereign rule and his great love. Mission and globalisation are not two different entities. We do not examine globalisation as a context in which mission and missionaries operate. For ages already, the commission, given to Christ's disciples, has been an intrinsic part of the process of globalisation. Christians are the initiators of the interaction between local and global.

\section{Redefining mission}

So Christians all over the world initiate a new missiological paradigm. The mission concept, with its total set-up of convictions and values and methods, which were shared by the members of a society, are no longer the guidelines in our thinking on missions today. From time to time, the nature of the gospel has undergone redefinition. It was out of love for Christ that men and women went out 'saving souls for Christ'. William Carey (1991) issued in his historic appeal for missionary action on the basis that Christians ought to use all means for the spread of the gospel. His phraseology was instinctively broad and inclusive - it ranged from direct preaching to agricultural development, Bible translation and printing, from the founding of local churches to the creating of institutions of higher education.

In the 19th century a huge number of missionaries from Europe and America entered the heartlands of Africa and Asia, preaching and establishing churches along denominational lines. Due to the influence of the yearly Keswick Conventions at the end of the 19th century, interdenominational organisations - many known as faith missions - sent missionaries to preach and teach, and it was for the new Christians to organise their own churches. The Keswick missionary, Amy Carmichael (1867-1951), (she was from Presbyterian stock) did not work along denominational lines and in her words 'dropped all labels', for she found no denominations in the New Testament (Elliott 1987:237; Houghton 1954:37). Between 1880 and 1914 the Social Gospel model grew out of liberal theological assumptions. It became a force in the United States and was characterised by three ideas: the immanence of God, the organic view of society, and the presence of the kingdom of God here and now (Coleman 1980:207).

In the 1910 Edinburgh mission conference, the talks were focused on getting 'a Christian nation'. 'There is an imperative spiritual demand that the national life and influence as a whole will be Christianised' (Van 't Hof 1972:52). The evangelistic emphasis on conversion, combined with efforts to reform the structures of society, was its first demand. In one and another way, it was optimistic and idealistic with a lot of rational thought, but all the ideas were scattered by the 
atrocities and massive killings in trenches of the war stricken Europe. The vision of Edinburgh sank away by the global disasters since the outbreak of the First World War in 1914. The 20th century was extraordinary in its violence and the West that once sent missionaries across the world now was in desperate need of mission.

In the 20th century the content of the gospel has often been described in terms of a dualism: word and deed, or proclamation and service. Politicising the gospel and sociopolitical strategy dominated in the great conferences of the World Council of Churches (WCC) in Uppsala (1968) and Bangkok (1972). After the First and Second World War we see a lot of violence accompanying the dismantling of colonialism, expulsion of missionaries, progress of secularism and the resurgence of world religions. In the second half of this century a complete new mission strategy was needed. One can say that, due to the Missionary Council meeting in Willingen (1952) with its mission concept as missio Dei, the previous Christological based understanding of the church became something of the past. Not conversion but entering the kingdom of God became theologically the mission issue (cf. Bosch 2001:368) focussing on word and deed. In 1984 the statement Mission and Evangelism by the WCC, the Commission on Mission and Evangelism tried to restore mission and evangelism on the WCC agenda.

\section{Competitive goals}

Earlier generations would have wondered about this dualism of word and deed, because in their view this happened already unintentionally. Is it too simple to suggest that this principle was followed in former generations without mentioning the words globalisation and holistic? They had, as their leading guide the Bible, and the Bible does not contain any discussion on strategies of 'evangelistic preaching' and 'social service'. Nor is there any attempt to contrast one with the other or to establish the primacy of one over another. Our modern generation managed to introduce into our reading of the Bible a distinctly modern problem. Missionaries in earlier centuries were not burdened with formulations. From academic side to missionary training centres the problems have arisen primarily at those points where there is insisted on keeping the elements separated and compartmentalised with differing values assigned on the parts. These values were derived from certain assumptions made by competing schools of thought as they have engaged in polemics against one another. In spite of the fact that this is a non-issue on biblical, theological, historical and practical grounds, it has been the centre of intense debate in our time. It is my argument that we still undergo the influence from the intellectual product shaped by the Enlightenment of the 18th century. As was thought then, man can get the truth through rational thinking, while the biblical truth was treated with great scepticism. Practical problems could be solved by developing new technologies and knowledge in all areas, based on an increasing degree of specialisation, continued to spread rapidly. Since then science has dictated methodology and the norms for truth. Western theology, whether liberal, conservative or evangelical, is heavily acculturated. Most people live in a situation with continuous activity between the empirical and the spiritual world and faces issues for which Western theology has no resources. Christian scholars have to come to terms with the challenge of science in biblical studies and in missions. Engagement of biblical thinking and the Christian tradition with the very ancient cultures in Asia, Africa and Latin America could open an era of theological understanding.

Is it possible today to make the Christian faith credible in relation to the modern worldview without being accused and being discredited as a fundamentalist, and lose more and more influence as vital force in our modern society? Can we avoid that the old conflict dominates today's generation in their effort to obey to Christ's last command? The debate for a holistic ministry (cf. the debate in Evangelical Missions Quarterly in 1999) is on-going in our time. In holistic ministry, evangelism is not a central part of missions in the world. Nineteenth century evangelicalism as observed, had a clear focus: 'The evangelical paradigm of conversion begins with the personal knowledge of sin, moves to personal trust in Christ's finished work, and issues in a godly personal life' (Walls 1996:83). In faithfulness to the Scriptures, the church will operate in an effective way, to engage the cultural context. It will re-invent itself to an active contribution to revive Christianity faithful to the Scriptures. From a biblical perspective it is the autonomist man under the directions of the gospel! That this is not a dream but a reality as seen in China's church today where it went from survival to revival. Robbed of its missionaries in 1951 when Mao moved in, many predicted the death of China's church. Instead of decline today's China is enjoying unprecedent church growth.

\section{Overcoming the dualism - an example for today}

At the end of the 19th century, the eschatological vision of 'Thy kingdom come' was planted in the hearts of many missionaries and mission agencies. ${ }^{3}$ For example in India, an enormous country with a dominant Hindu population, the Christians tried to evangelise, teach and heal the sick. Especially in the north and in the south of India rather strong churches emerged. In the south in Tamil Nadu (Tinnevelly District), there was a strong Anglican presence. In 1895, the 28 years old Irish missionary, Amy Carmichael from Ulster Presbyterian background and strongly influenced by Keswick holiness theology, landed in Madras. Via Bangalore she joined in 1897 the Tinnevelly missionary, Reverend Thomas Walker, in itinerary work. In 1904 she settled in Dohnavur where she started The Dohnavur Fellowship (DF). During her evangelistic work she discovered the secret traffic of little girls (often still babies) and boys sold to the temples to serve as devadasis. These girls were 'married to the gods' and would serve in Hindu temples, but in reality they were forced in temple prostitution. The DF saved hundreds of these girls.

3.Compare Robert (2003); also in the mission principles of the founder of the China Inland Mission (CIM), Hudson Taylor, and in the early representatives of the Keswick Convention. 
They got a good education, medical care and the DF secured good marriage partners for them in order that Christian families would set an example in the society. Amy Carmichael longed for all to know Jesus Christ, but also cared for their wellbeing and future. Next to a church, a hospital was build, languages were taught, holiday camps were organised, and agriculture and veterinary skills were developed. From the beginning until today the credo of the DF is 'Christ first', and out of that the needs of the people should be handled in a practical way. That meant that teachers in school were evangelists in their free time and doctors as well as nurses were involved in evangelistic outreach programs. It is known that one of the medicals in Dohnavur had his Greek New Testament in his pocket. Since the beginning of the DF there is mutual respect between the DF and the community. When Amy Carmichael died in 1951 hundreds of Christians and Hindus paid her respect. This type of mission work endures the time. People from all over the world do not ask for the gospel, but they need it! They do not wait for highly sophisticated academic words and theories, but they need in clear words the Light of the world, an understanding heart and an outstretched hand.

It is inspiring to know that Amy Carmichael longed to see Christians worshipping and living together as in the Early Church. In Dohnavur we see that the fruit of the gospel proclamation is, in effect, the realisation of the demands of a Protestant (Reformed evangelical) worldview. Here the gospel transforms the heart as well as the surrounding community. The missionaries had in their hearts to work in the conviction that it is God's business to convert and renew individual hearts which, in turn, leads to the building of a civil society and nation. Missionary work in this way shows signs of vibrant piety, major driving forces of church growth and mobilises people into a committed life. This mission view overcomes the dichotomy of body and soul, flesh and spirit, word and deed. Before, the word holistic was used in mission circles where it was already practiced. The abovementioned example shows that evangelism and service, outreach and healing, witness and development are integral elements in missionary work. The outcome was that people got saved and practices of child prostitution that lasted for centuries, diminished, that is, forbidden by government law in 1947. This missionary work is not outdated. Many young people in South India today are triggered to use all their energy in seeking God's glory and his kingdom. 'Thy kingdom come, thy will be done' is everywhere and in all times the transformational motivation for the church.

\section{Changing mission paradigm}

The landscape and context for global mission has changed in more than one way. Perspectives and approaches of the 19th and early 20th century are no longer adequate or cannot be done in the same way as described above. The Western world is no longer the centre of all Christian missionary movement. Nowadays, the United States is the world's fourth largest mission field with a traditional 'Christian' population becoming increasingly secularised (Global Mission n.d.:13).
More than 2000 different evangelisation plans at the beginning of 1990 were focussed on the year 2000. In an attempt to help these plans to be realised, the AD2000 \& Beyond movement was established with the goal of addressing the challenge of uniting churches from the West with churches of the Two-Thirds World countries. This was done by building bridges between young and old Christian leaders, encouraging cooperation among charismatic and traditional Christian movements to promote the:

understanding of God's call for both evangelism and social responsibility, sacrificial service in the world and preaching the gospel of Christ to the world, of both Word and deed, proclamation and presence (AD2000 \& Beyond 1997). ${ }^{4}$

The question raised was: How will we be faithful to the gospel in the 21st century to be relevant to the culture in which the message is proclaimed without being syncretistic (cf. Goheen 2014:270)? This question hits the essence of present-day mission work. Contextualisation is being involved in every part of life. Hermeneutical questions and solutions have to be taken seriously in order for the biblical message to enter people's hearts and be of influence in their daily life. Modern life changes continually and it is a huge task for the church and mission to stay informed with today's issues and to have in mind that the biblical truth cannot be changed. What relevance or authority has the gospel in a secular pluralist society? The gospel, according to Newbigin, 'the living memory of the church' (Weston 2006:246) is handed over from generation to generation and has the intrinsic narrative power to do an appeal to modern society in faith and prayer that the Holy Spirit will create a living relation between man and the Saviour. In this way we prevent that the gospel is accepted by all sorts of secular motives. It is not my intention to add another plan to the huge number of plans of the AD2000 \& Beyond movement, but to identify one general focal point, that is, to honour God by obeying to his commission. This is God's priority, using his people to identify and highlight the groups of people in the world who have the least exposure to the gospel.

Can the present time be described as 'a kairos, a critical time, for missiology' (Thomas 1990:14)? There are certain realities, which could verify this thought. We see a shift in the Christian axis, which occurred within the last two decades, moving ecclesiastical gravity from the Northern to the Southern hemisphere. In Africa as well as in Asia new centres of Christian vitality and creativity are seen in theological thinking and expression from new upcoming churches. Theological and missiological ferment flows from this new reality, revitalising influence of dynamic Christian movements in other parts of the world. It seems that, in Europe, the huge influx of refugees from the Middle East and Africa no longer demands that the churches cross any border. There is no excuse for theoretical theological reflexion from the balcony. Instead of going over there, God brings them to our doorstep and churches have to respond.

4.This website is no longer being updated. 
The size of the world's non-Christian population is enormous. Out of the total world population of 5.4 billion in 1992, it is estimated that 3.6 billion are not Christian. In today's world, the cities are like giant magnets attracting people. Far more than 50 years ago, the majority of non-Christians do not live a geographically long distant from a church, although there are cultural distances. Tokyo, with its 35 million inhabitants and still more people drawn in from rural areas, demonstrates what is said 'The entire planet is becoming highly urbanized' (Ortiz \& Baker 2002:31). A migration is happening on all six continents, not only because of more job possibilities, but also due to famine, disaster and war (cf. NRCMedia 2014)

\section{From everywhere to everywhere ${ }^{5}$}

Our generation is known as one of strategic optimists, 'a generation with more dreams than memories' (Friedman 2005:635; Nazir-Ali 1990). Christians have not lost their dreams that once the earth will be full of the knowledge of the Lord. Since William Carey went to India, the Protestant mission movement with the vision to bring the lost ones to Christ is the same throughout the years. Over the time this vision has been reshaped by changing circumstances. In this second decade of the 21st century it is very different from what it was in the 19th century. Thomas L. Friedman (2005) has given us a clear explanation of the forces that in the space of a mere 20 years have so dramatically shrunk the world with his award winning The world is flat. A woman operator in a call-centre in India sells a credit card she could never afford herself to a customer in Los Angeles. And somewhere in a bunker in the Nevada desert a drone pilot directs his drone to a place somewhere in Afghanistan to eliminate a terrorist. What is going on in our present world presents us with new possibilities, new challenges, but also new dangers. What happens in the secular world influences our spiritual realm.

We have not lost our memory, for we remember the faithfulness of God and therefore we look forward into our 21st century. In a world where the claim of absolute lordship for Christ to whom, in Paul's phrase, 'every knee shall bow', is denied, we are part of our post-postmodern generation, known as unwilling to surrender to any authority. To the attitude of 'we will not that this man reigns over us' (Lk 19; 14), Christians can only reply by quality of life and testimony. They will demonstrate that to surrender to Christ is expressed in terms of vulnerable love in witnessing in service. All organisations have a tendency towards decay - also the old mission organisations and mission methods do change; not so the message! Any difficulties for mission work in our era we see as opportunities. We know of the obstacles, for where Christ's disciples are, the devil does not want them there at all!

Because of a changing context and incredible new advancements in technology, we see that new methods for missions continue to appear. This creates exciting new possibilities for communicating God's eternal love for all people. Times may change, but we know of an unchanging God. Due to the continuing and often phenomenal growth of the emerging churches, it indicates that they have taken full responsibility for propagation of the gospel in their context. Practically this means that the expatriate missionaries move into support roles, equipping and guiding new churches in their evangelistic work. The mission work of the church is only then effective in God's mission when it embraces the wide diversity of people and their gifts. Christian mission wishes to market their particular brand of Christianity. It is this one issue: the centrality of Christ and the necessity of witnessing to and proclaiming his name with faith and conviction. Stressed already by Kraemer (1963:367) who, for the Tambaram Conference in 1938, wrote: 'Christianity never can give up its much-criticized exclusiveness, because if it did it would deny its prophetic core, that is to say, its life and essence.' The inner conviction is that Christ 'is the Truth and the sole One, who is entitled to claim supreme loyalty from everyone' (cf. Kraemer 1963:290, [Kraemer's emphasis]).

In making known Christ's name in the present world, one can choose to use the classical forms of evangelisation, education and social welfare service, but also to grasp the opportunities offered by globalisation in terms of communication, audio-visual aids, et cetera. It will therefore be possible to reach the unreached from everywhere to everywhere and go anywhere! The General Board of Global Ministries has made a start toward building a truly international, multicultural and interracial community of missionaries. To name a few, Christians from Africa are now serving in Southeast Asia; from China, Mexico and Brazil missionaries serve in the USA; from the Philippines Christ's messengers serve in Japan, Liberia and Cambodia. Still, we have not yet seen all the challenges that a mission strategy from 'everywhere to everywhere' presents. Evangelical Christian churches now have a highly developed technological presence and web-related mission information facilitates Christian presence in even strict closed countries for the gospel and in breaking new grounds. Global Mapping International (GMI) is becoming a clearinghouse for information about the task of worldwide mission enterprise. GMI provides professional services that enhance the effectiveness of international Christian mission. Mission leaders, pastors, professors, students and prayer teams learn to plan, understand, coordinate and communicate their world and work. A globalised church is therefore emerging from our globalised world. Modern missionaries are involved in the worldwide web and will use the new technology for reaching the unreached. ${ }^{6}$

The inclusive approach of churches needs strengthening and we should be ready to transcend any particular culture. Missionaries build bridges in two different worlds and are prepared to go the 'second mile'. They will equip appropriate local mission service so as to avoid the emergence of replicas of European and American style churches. Listen to Stanley Jones (1925):

6.Compare the initiative of Dr. Marten Visser (2016) of The Netherlands 
When I was called to the ministry, I had a vague notion that I was to be God's lawyer - I was to argue his case for Him and put it up brilliantly [...] I my ministry (I learned) I was to be, not God's lawyer, but His witness. That would mean that there would have to be living communication with Christ so that there would always be something to pass on. (pp. 141-142)

The understanding of Christ as a transformer of cultures and the existence of satanic forces, which prevent people from coming to faith, leads us to the point to take these things seriously. Our generation has to catch God's vision, face the fears and rise up to serve his cause in this world. We have to embrace this vision and not to fight against it.

\section{Hiding the key}

A part of this article was prepared on the day that the British MP, Jo Cox, was murdered. ${ }^{7}$ With last years' terrorist attacks in Paris, Berlin, London and recently in Nice, Barcelona and Brussels where many innocent people lost their lives it is clear that in a world where people are killed at random, our world has lost its innocence. In a world where people are prepared to blow themselves up believing to please their god, the global church should call us to an earnest response. We are encouraged seeing a world of opportunity before us where we tell the world of our God who so loved the world that he gave his only Son. Our present mission situation is certainly daunting, but in incredible ways, we are finding God at work. His messengers go out in this time with the gospel to deepen and extend the witness of salvation. The dynamic power of the gospel always finds a way like water coming from the mountains searching in an irresistible way its route downwards. Think only of the accelerating situation of evangelism in China where it is expected that by 2025 Christians in China will outnumber the total of Europe. Three hundred years of Enlightenment influence on Western society has put church and religion on the defensive, and the worship of God more and more excluded from public life and consigned to the private domain. In various Western countries the wearing of Christian symbols in public for government officials or preaching in jails about sin and graces has been banned. Is it necessary for this generation of missionaries to change the mission goal of those who went out 100 years ago? We experience a decline of Christianity, but looking further we even see global expansion. It is estimated that by 1500 about 100 million Christians lived on our planet and by the entrance of our millennium about 2 billion Christians were scattered all over the world. There is a difference in decline locally; however a wider view shows signs of life. Churches grow tremendous in Africa and China, the education force of local churches supports many students and churches take the initiative for social action.

Bosch follows the German missiologist, Gensichen, by proposing a dual functioning of missiology within the wider framework of theology. He refers to a dimensional aspect to missiology and an intentional aspect by highlighting the relevance of mission to the world and permeating all

7.June 16, 2016. the disciplines. It covers many sectors of the theological spectrum. He stresses that theology, that is missiology, has to be theologia viatorum [theology on the road] (Bosch 2001:496. In general, we can say that missiology fulfils a much-needed critical function within the theological curriculum and practice. It challenges the theological disciplines of churches all over the world with mission as its conscience. Missionminded churches and missionaries challenge the worldwide church to venture outside their comfort zones to open passable ways for the church in the 21st century and to rethink its concept of the church.

The intentional task of missiology cannot be left out; it has its own proper task as a discipline to perform. Here Conn (in Ortiz \& Baker 2002) gives a wide range like evangelism, enculturation, dialogue, liberation, poverty and absence of faith as challenges for the Third World and the Western church. I would limit Bosch's (2001) and Conn's (in Ortiz \& Baker 2002) agenda by emphasising that the heart of the intentional aspect has to deal with the 'one thing necessary': that people will get to know Christ Jesus as their Saviour. So preach, teach, pray, reflect, repent and renew. Christians live as signs of hope in this present world. If we are too reluctant to admit that it is, Zwemer said 100 years ago, 'because you have forgotten to wind your watch. If you say that the doors are shut, maybe you are hiding the key in your pocket' (St John 1990:150).

The plea for an integrative contextual missiology has landed in many churches and mission organisations. If we want to be at the cutting edge where the gospel of Christ encounters the world, limitation is natural. It would be sad if we have to experience limitation, while we have not yet even started to see the new possibilities. Missionary work by its nature is always looking forward and if mission involvement in our era will succeed, every discipline in theology has to take part in the dynamic search for a genuine service in which God, the Maker of the earth, is honoured.

Those captured in the expressive individualism of postmodernity, need the gospel that will set them free in Christ and to see the other through him. It is too easy to focus only on the needy in this world, because the gospel is in jeopardy when missions come to believe that delivering the "cup of cold water" is just as important as dispensing "the water of life"' (Brant 2004:5). Christians are with open eyes focussed on the future, eager to see God at work in this world. Here we do not propagate mission methods of the past and glorify mission successes of the past. We are not called to success, but to faithfulness and not only look back, for 'we are not put in God's showroom. God never has museums' (Chambers 2000:940). No huge mission enterprise is labelled with any denominational name or mission organisation. God's people everywhere in the world are mobilised for mission work and respond to the various contexts in ways that offer creative solutions for mission work in the 21st century. What communicates now is basically personal authenticity (Harley 2008:20). 


\section{Conclusion}

The overall picture of mission at the 1910 conference in Edinburgh was of mission as Christianising the world (Van 't Hof 1972:52). From a theological point of view the transition, initiated in the second part of the 20th century, has reached a stage where the point of departure of Edinburgh has been passed. Contextual theological models arise all over the world which implies that Western theological dominance is broken down. It is certain that, in this changing context, the focus is on the congregations as the place of God's work in the world. They have to work out God's mandate even when this implies suffering. Congregations in their context become the primary location of God's redemptive presence in today's world. We have seen that this can go in parallel with the danger of losing the exclusiveness of Christ as the only Saviour of the world. Can we avoid this? When we continue working only from the perspective of either word or deed, we fail because it causes us to miss the sense of wholeness that, for the New Testament, was foundational to all else. The mission of the triune God is to establish his reign throughout the whole world where soul and body are included. The urbanisation of the world requires, in our era, a different set of needs and an adequate response from mission strategists. Modern missionaries are involved in the worldwide web and will use the new technology for reaching the unreached. In a world where feelings of the people are important, all opinions and lifestyles are acceptable and life is like living in a supermarket full ideology, God's unique claim to the whole world is considered as an offence. In this situation the mentality to belong to a church or belonging to a denomination for reasons of social standing will diminish drastically, because, for people to have a reputable social status and class, do not need the church anymore, because other life values offer higher status.

A church, true to the gospel as fundamental for belief and life and therefore contradicting to the world, is relevant for the society when, at the same time, by an authentic fellowship and full dedication, the society is touched by the Christian hope. Then the church is really an avant garde of justice and Jenkins (2002) vision will become a reality. Today's Christianity is no longer an European or American religion, but it is multicultural. This situation is not new for the Christian church. The church was born in a religiously plural society (cf. Newbigin in Weston 2006:172).

In an authentic way, in a serving and healing ministry, one may call it holistic; it continues its witness amidst opposition and suffering. In contrast to activist endeavours, we note here that this model tends to be more situational than programmatic. All that Christ did was part of a whole and we cannot correct that without adequate knowledge of this scientific worldview. Christ knew what he did; from a dynamic centre he looked for the heart of the people and, in doing it, it awakened faith and brought wholeness. Already in 1984 Edwards made a strong appeal, when he suggested that 'in the future, when anti-colonial passions themselves belong to history, justice may be done to the Victorian missionaries' (Edwards 1984:316). That time has come, for by their lives and their struggles, they have earned the right to be heard and to press their claims with confidence. In these hectic everyday lives, it is a desideratum to establish, in mission circles, technology-free areas to focus on - and spend extended time to kneel before our heavenly Father for missionary guidance and passion.

As a missionary in Africa, I walked a path with my African brothers and sisters and developed the attitude of 'going the second mile'. I listened to their stories and explored with them the Scriptures to meet him, who is the Saviour of humankind. Walking together in God's mission implies mutuality and interdependence, underlined by Robert (in Saane 2010:42) who said that missionary priorities for the 21st century have to be moulded in relational ways of mission. We journey together side by side, with neither companion ahead or behind, above or below the other. It also means equal sharing of decision-making and resources. It is for the newborn Christians to develop their way of worship and to start their own missionary work. We do ourselves an injustice when we would not use the experience, the love, zeal and passion of former generations who had one vision. We, too, will benefit from their experiences to shape our missionary intention. The older missionary societies will have to reexamine their mission practices and to be creative not to lose their old mission vision, but in inviting new participants heading together hand in hand in taking responsibility for God's mission in the 21st century context, crossing cultural and national boundaries. We focus on understanding God's dealing with his people in the past and to apply God's principles in today's evangelism to move people from where they are to where God wants them to be. The first aim of Christians in this world is to honour God and, hereby, to die to themself. The following words written in 1934 by the Dutch missiologist, J.H. Bavinck (1934), today 80 years later, have the same value as in the time they were written:

There are still great things we may expect in belief. We live in a time of a tremendous crisis, of struggle and confusion. From all sides this modern world is shaken and nobody can say, to what side everything will develop. Happy is the man, who believes and waits and knows that Jesus Christ is the power in the middle of this wonderful world to do great deeds. If only we learn also to expect great deeds from Him. (p. 233, [author's translation])

For the old as well for the new generation of missionaries, mission work has many risks and uncertainties. But they had and have the last certainty in what Jesus Christ said: 'You did not choose Me, but I choose you and appointed you that you should go and bear fruit and that your fruit should abide' (Jn 15; 16). Therefore we believe mission work is filled with so many significant opportunities in order to reach for our time the old Protestant mission goal of the manifestatio gratia Dei. To see that those who stand afar will be brought nearby and that in the fellowship with God, He will be honoured. The church needs people, called by God for mission work, people of prayer and churches who have vision to respond to commission members to go into the world and who can operate in a flexible, continuous changing situation. However, 
expertise, flexibility and busyness are not the first ingredients for successful mission. The ultimate motive what makes mission work urgent is that, in everything and everywhere, God is glorified.

With an open eye and a compassionate heart, those who are sent, look around in this complex world with its tremendous sores, and confronted with inexorable forces, love has amazing ways to obey Christ's last commend and take the step knowing that only the gospel of Jesus Christ is relevant in our present situation. As Herman Paul explains (2017):

Experiences of the loss of old treasured values must not be made absolute, but be relativized to perspective and be related to a 'larger story': a story of God who through the ages will teach his children to have confidence in him. (p. 151)

Times and circumstances have changed - also what mission work in concretion contains and how it is done and fits in with the whole. Missionaries are blessed people, for they are the far-seeing who are watching for great things and listen for the prophetic voices. We do not swim against the tide of history, but those, busy in Christ's commission on the hard horizontal sphere, know they are placed in the wonderful vertical field of force that Christ himself by his Spirit, sustains his flock and opens unprecedented windows of opportunities for missionary action. Blessed are the far-seeing men and women who are always watching for great things, bending forward and listening for the prophetic voices.

\section{Acknowledgements Competing interests}

The author declares that he has no financial or personal relationships which may have inappropriately influenced him in writing this article.

\section{References}

AD2000 and beyond, 1997, A church for every people and the gospel for every person by the Year 2000, viewed 17 May 2017, from www.ad2000.org

Bangura, J.B., 2013, 'The charismatic movement in Sierra Leone (1980-2010), A missio-historical analysis in view of African culture, prosperity gospel and power theology', PhD thesis, VU (Free University), VU Publications, Amsterdam.

Bavinck, J.H., 1934, Christus en de Mystiek van het Oosten, Kok, Kampen.

Bliese, R.H., 1997, 'Globalization', in K. Müller, T. Sundermeier, S.B. Bevans \& R.H. Bliese (eds.), Dictionary of mission: Theology, history, perspectives, pp. 172-178, Orbis Books, Maryknoll, NY.

Bosch, D.J., 2001 [1991], Transforming mission: Paradigm shifts in theology of mission, Orbis Books, Maryknoll, NY.

Brant, H., 2004, Redefining missions for the 21st century, SIM, Addis Ababa

Carey, W., 1991 [1792], An enquiry into the obligations of Christians to use every means for the conversion of the heathens, Baptist Missionary Society, Oxford.
Chambers, O., 1929, 'Our brilliant heritage', in O. Chambers (ed.), The complete works, pp. 914-956, Discovery House Publications, Grand Rapids, MI.

Coleman, R., 1980, Issues in theological conflict, Eerdmans, Grand Rapids, MI.

Edwards, D.L., 1984, Christian England, vol. 3, William Collins \& Co. Ltd., London.

Elliott, E., 1987, A chance to die, Paternoster Publishing, Carlisle.

Friedman, T.L., 2005, The world is flat: The globalized world in the twenty-first century, Penguin Books, Strand, London.

Global mission, n.d., 'Global mission in the twenty-first century', in God's mission, Evangelical Lutheran Church, viewed 19 May 2017, from download.elca.org/.../ Global_Mission_in21stAmerica

Goheen, M.W., 2014, Introducing Christian mission today, IVP, Downers Grove, IL.

Hardmeier, R., 2012, Geliebte welt, Auf dem Weg zu einem neuen missionarischen Paradigma, Neufeld Verlag, Schwarzenfeld.

Harley, D.C., 2008, 'Proclamation and mission of god', Mission round table 4(1), 16-21. Hiebert, P.G., 1999, Missiological implications of epistemological shifts, Trinity Press International, Harrisburg, PA.

Houghton, F., 1954, Amy Carmichael of Dohnavur, SPCK, London.

Jenkins, P., 2002, The next Christendom: The coming of global Christianity, Oxford University Press, Oxford.

Jones, E.S., 1925, The Christ on the Indian road, Abbingdon Press, New York.

Kähler, M., 1971, Schriften zur Christologie und Mission, Chr. Kaiser Verlag, Münich.

Kraemer, H., 1963, The Christian message in a non-Christian world, 6th edn., Kregel Publications, Grand Rapids, MI.

Landes, R., 2001, Y2K hangover and the new millennium, Boston University Centre for Millennial Studies, Boston, MA., viewed 17 May 2017, from www.mille/people/ rlpages/y2khangoverandnewmille.html

Nazir-Ali, M., 1990, From everywhere to everywhere: A world view of Christian mission, Collins, London.

NRCMedia, 2014, viewed 17 May 2017, from www.nrc.nl/2014/06/20

Ortiz, M. \& Baker, S.S. (eds.), 2002, The urban face of mission: Ministering the Gospel in a diverse and changing world, P\&R Publishing, Phillipsburg, NJ.

Packer, J.I., 1977, 'What is evangelism?', in H. Conn (ed.), Theological perspectives on church growth, pp. 91-105, P\&R Publishing Co., Nutley, NJ.

Paul, H., 2017, De slag om het hart: Over secularisatie van verlangen, Boekencentrum, Utrecht.

Robert, D.L. 2003, 'Occupy until I come': A.T. Pierson and the evangelization of the world, William B. Eerdmans, Grand Rapids, MI.

Robertson, R., 1982, Globalization: Social theory and global culture, Sage, London.

Saane, W.V., 2010, “"Geworteld in hoop", Dana Robert over missionaire vrouwen en Edinburgh 1910-2010', Tussen Ruimte: Tijdschrift voor Interculturele Theologie 3(1), 39-44 Kok, Kampen.

St. John, P., 1990, Until the day breaks ..., OM Publishing, Carlisle.

Thomas, N., 1990, 'Globalization and the teaching of mission', Missiology 18(1), 13-23.

Van Engen, C.E. (ed.), 2008, Paradigm shifts in Christian witness, Orbis Books, Maryknoll, NY

Van 't Hof, I.P.C., 1972, Op zoek naar het geheim van de zending. In dialoog met de Wereld zendingsconferenties 1910-1963, Veenman \& Zonen N.V., Wageningen.

Visser, M., 2016, Dr. Marten Visser lanceert Facebook pagina 'EO Duidelijk', viewed 17 May 2017, from https://www.rd.nl/vandaag/binnenland/dr-marten-visserlanceert-facebookpagina-eo-duidelijk-1.1130085

Walls, A.F., 1996, The missionary movement in Christian history, Orbis Books, Maryknoll, NY.

WEAG see World Evangelical Alliance Working Group on Globalization.

World Evangelical Alliance Working Group on Globalization, 2003, 'Introduction', in R. Tiplady (ed.), One world or many, globalization and world mission, 1-11, William Carey Library, Pasadena.

Weston, P. (ed.), 2006, Lesslie Newbigin: Missionary Theologian: A reader, SPCK, London.

World's Student Christian Federation, 1960, History lessons for tomorrow's mission, SCM Press, London. 